\title{
The Consept of "New" Paternalism and Its Realisation within The State Regualtion of Economy
}

\author{
Bagautdinova N. ${ }^{a}$ \\ Sarkin A.b \\ Averyanov B.c \\ Arzhantseva N.d
}

a bc d Kazan Federal University, Kazan, 420008, Russia

\section{Doi:10.5901/mjss.2014.v5n12p27}

\section{Abstract.}

In the article the authors prove the methodological platform of new paternalistic economy which is treated as a form of implementation of standard (estimated) concepts of the theory of behavioural (behaviouristic) economy, also the contradictions of new paternalistic economy are formulated, additional arguments in favor of the necessity of state regulation of economic events and processes are suggested. The method of forecasting the results of the industrial enterprise activity functioning in the conditions of new paternalistic economy is worked out. This method is based on the assessment of current results of this activity, on the existing tendencies of development, dynamics of macroenvironment of the economic entity, and also a complex assessment of current state and prospects of development of the enterprise. All this have found their application in scenario forecasting the results of the activity of the enterprises of the Russian industrial complex.

Keywords: Behavioural economy, paternalistic state, state regulation of economy, normative standards, behavioural anomalies.

\section{Introduction}

The experience of historical and economic development of human civilization testifies that, despite distinctions in character and sources of progressive dynamics of particular state institutions, the main direction of prevailing movement of indicators is defined by the ratio of market and state forces in economic system. At the same time recognition of the priority of the market or state plays the role of a watershed between the main economic concepts $[1,4]$.

Neoclassicism as the orthodox movement (mainstream) recognizing market self-regulation as the priority, and Keynesianism giving preference to the state intervention in economic events and processes. Despite considerable number of works devoted to the laws and regularities of functioning of national economic systems, at present there is no current concept of progressive development of human civilization which would allow the authentic forecast of dynamics of main economic indicators on the basis of methodological platform alternative to the mainstream.

\section{Methodology}

Modern theories of economic development having different understanding of the sources of progressive macroeconomic dynamics (ex. the theory of "economic basis", the staple theory, the theory of sectors, the theory of the poles of growth, the neoclassical theory of growth, the theory of interregional trade, the theory of an inventory cycle, entrepreneurial theories, models of new economic geography, etc.), proceed from the recognition of the neoclassical postulate of rationality of the choice and an objectivity axiom according to which the tools for economic analysis were created.

In reality economic agents don't possess a strictly arranged set of preferences and perfect information that would hold up the development of authentic social and economic forecasts and the formation of complete contracts. The assumptions accepted within the neoclassical paradigm don't allow to consider in full extent the anomaly in temporary preferences, systematic mistakes (non-regressive predictions, etc.), anomalies in economic behavior (preference of the current consumption, impulse investment, gregarious behavior and a trap of the recessed expenses, etc.), anomalies in market prices and incomes (a dividend trap, calendar effect, etc.) [2, 5. 8]. Thereby, the choice of economic agents based on the imprinting of random factors isn't possible to predict. 
The research shows that economic agents don't realize their own interests in a full measure and act in spite of them. The understanding of limitation of gnoseological potential of the neoclassical paradigm resulted in realizing the necessity of the development of behavioural (behaviouristic) economy the object of research of which is the process of implementation of a choice with the account to the influence on the decision taken on the basis of assessment of cognitive and behavioural restrictions of rationality. Recognition of the composition of factors defining the contents of the taken decision involves the development of institutes which will allow to overcome the revealed restrictions of rationality. The content of the subject defined the features of analytical tools which are mainly presented by experimental methods.

The behavioural economy acts as the theoretical base for new paternalism which represents by itself a coherent concept and a certain stage of development of human civilization, which is characterized by the state performing the function of formation and implantation of normative (estimating) standards of behavior into preferences of economic agents. New paternalistic economy differs significantly from the welfare economy, recognizing the existence of shortcomings ("failures") of the market and the need for their regulation. The role of shortcomings is played by the inefficient allocation of resources and incomes the recognition of which defines the possibility of usage of the methods of indirect regulation (budgetary-financial and monetary-credit), but at the same time prevents paternalistic intervention [3, $10,11]$. The completeness of satisfaction of the needs of individuals acts as the normative standard, allowing to estimate the welfare of a particular individual.

Thus, welfare of society is defined as the sum of welfares of individuals living in it. New paternalistic economy alongside with the specified shortcomings admits the behavioural anomalies coming from the irrationality of its agents which expands borders of the state intervention and provides the necessity for replacement of the methods of indirect regulation by the methods of direct influence, presented by methods of institutional design. Thus, the present stage of development of Russian economy is treated as new paternalistic economy in which the intervention of the state into the economic processes is focused on the replacement of irrational preferences by the rational. New paternalistic economy differs from the old paternalism in the following: the latter ignored preferences and interests of economic agents, replacing them by the interests of the principal, thus the realization of the principles of old paternalism assumed planning of religious and moral-ethical institutes governing the contract relations with the state participating in them $[6,7,14]$. New paternalism doesn't limit the freedom of choice of particular economic agents.

However, the state performs the function of structuring the field of decision-making. The paternalistic impact of the state on the structure of preferences of certain economic agents is focused on initiation of the actions directed onto the increase of their welfare. We consider as expedient those forms of state regulation which provide effective elimination of cognitive and behavioural mistakes.

\section{Results}

The conducted research showed that it isn't possible to consider paternalistic institutes as constituents of independent institutional structure of economy. They represent complementary institutes which carry out prohibiting (requirements to safety measures when performing certain types of work; statutory bar for drugs, smoking in public places; institutes of the system of state, i.e. mandatory pension insurance), stimulating (the institutes of a social tax refund stimulating expenses on education), supporting (the institutes directed on increase in producing the meritor benefits), manipulating the architecture of choice (the institutes setting an obligatory time lag for decision-making, for example, institutes of family law) and providing (the tax institutes promoting growth of direct expenses, connected with consumption of goods which bring harm to the health of population - alcoholic beverages, tobacco products, etc.).

Thereby, the discrete and variative character of paternalistic institutes which possess the potential ability to be implanted into the structure of institutional environment of post-industrial society that promotes its development. Their formation is considered as a difficult contradictory process of the realization of measures of institutional design with the participation of the state according to the principles of milestone and component completeness of the project, a sufficient variety of incentives, maximum security from the opportunistic behavior, partnership. Thus implanted institutes have to comply with the requirement of their collinearity with the existing ones which provides effective implementation of the functions assigned to them and doesn't lead to the rise of institutional risks.

The forecasting of profit on sales of a number of leading industrial enterprises of the Republic of Tatarstan for the period up to 2020 was carried out on the basis of the given method within the following basic scenarios:

initial, presupposing the realization of management of industrial enterprises operating within new paternalistic economy, using the tools of classical market economy;

- modified, offering the realization of management of industrial enterprises operating within new paternalistic economy, with the usage of mixed tools of management including both classical and special tools of new 
paternalistic economy;

- adaptive, offering realization of management of industrial enterprises operating within new paternalistic economy, with the usage of tools of management corresponding to this type of economy.

In the situation of institutional transformation a great value is given to the issue of how these transformations will correspond to the standard and valuable system and social expectations of the population, which defines the nature of antroposocietal correlation of present transformations in the system of industrial policy. If the central vector of institutional transformations is supposed to be connected to the changes in the system of its main entities with the responsibility redistribution from the state to non-state actors and an individual responsibility, it is important to understand how such transformations correspond to value representations and expectations of citizens, and also whether there were any changes in this sphere in recent years.

The results of the research testify that standard and value system of the most part of the population as regards to these changes is rather conservative and steady. As regards to obligation overwhelming part of respondents describe the state as the main and almost only subject of social policy amid which the assessment of capacity of all non-state actors looks insignificant. And during the past 10 years this system remained almost invariable. The results of the research of the opinions of all respondents allowed to single out the supporters of three main typological models of social policy. The vast majority of respondents, as is seen from table 1, are the supporters of paternalistic model of social policy, treating the state as its main and only subject.

In the interview there participated 1000 respondents representing employees of regional executive authorities, wage earners, owners and managers of the enterprises of the real economic sector of the Volga federal district [12, 13]. The second biggest group is constituted by the supporters of polysubject model of the economic policy, supporting equal distribution of responsibility for the results of functioning of real sector of economy between the state and various nonstate actors. And the third, the smallest group is constituted by the supporters of the liberal model supporting the principles of individual social responsibility. The comparison of the results of researches held in 2003 and 2013 allowed to ascertain an interesting fact: during the last 8 years these groups remained invariable in the quantitative and qualitative aspects.

Table 1: Distribution of answers to the question: "Who, in your opinion, has to bear the biggest responsibility for the state of the industrial complex of Russian economy", \%

\begin{tabular}{|l|c|c|}
\hline Variants of answers & 2003 г. & 2013 г. \\
\hline State & 66,4 & 65,8 \\
\hline Separate economic entities & 5,3 & 4,4 \\
\hline Public organizations & 1,2 & 1,2 \\
\hline Wage earners & 2,6 & 3,4 \\
\hline Every economic agent & 7,7 & 7,8 \\
\hline Everybody in the equal degree & 14,4 & 14,4 \\
\hline Can't answer & 2,4 & 3 \\
\hline
\end{tabular}

The produced social typification of these groups showed that they correspond the main layers constituting the social structure of modern Russian society: the bottom layer of the needy, the forming middle layer and the top layer of the well off. According to the experts, low-income and poor classes of population constitute about $60 \%$ in the present Russia, and among the needy there are about half the population of the country.

This very group which turned today into the main mass class within the vertical stratification of society represents the base group supporting the paternalistic model. The forming middle class constitutes today about $15 \%$ of the population and potentially presents the basic group supporting the mixed (polysubject) model of social policy and partially - the liberal one. In this respect, talking about a possible choice of strategy for transformation of industrial policy in Russia, it is important to understand, how the current value system and preferences of the population correspond to the assessment of the real situation.

The results of the research allowed to record the remaining over the last 10 years mismatch between social expectations, value system of the population concerning subjects of social policy and the real practice of its implementation that is reflected in table 2. 
Table 2: Correlation between value system of citizens concerning the subjects bearing responsibility for the results of the enterprises functioning in the industrial complex and the real practice, \%

\begin{tabular}{|l|c|c|c|c|}
\hline \multirow{2}{*}{ Variants of answers } & \multicolumn{2}{|c|}{ Who should bear the biggest part of responsibility } & \multicolumn{2}{|c|}{ Who bears the responsibility } \\
\cline { 2 - 5 } & 2003 & 2013 & 2003 & 2013 \\
\hline State & 66,4 & 65,8 & 12,7 & 24,2 \\
\hline Separate economic entities & 5,3 & 4,4 & 4,1 & 3,8 \\
\hline Public organizations & 1,2 & 1,2 & 1,2 & 1,4 \\
\hline Wage earners & 2,6 & 3,4 & 12,5 & 10,4 \\
\hline Every economic agent & 7,7 & 7,8 & 35 & 40,4 \\
\hline Nobody & - & - & 21,8 & - \\
\hline Everyone in the equal degree & 14,4 & 14,4 & 4,3 & 5,2 \\
\hline Can't answer & 2,4 & 3 & 8,4 & 14,6 \\
\hline
\end{tabular}

Amid the mass low-income class there prevails a forced individual social responsibility and support in family and friendly networks. In spite of the fact that during 10 years in the estimates of respondents there was a certain increase of a statehood as the real subject of industrial policy (from 12 to $24 \%$ ), the expectations from the state to perform economic functions in the sphere of industrial production happen to be unsatisfied. Thus the fixed increase of the assessment of the real role of state is the result of activation of industrial policy of the state.

\section{Conclusions}

Globalization of economic space and the statement of its polycentric organization determine the impossibility of practical application of the methodology of collective individualism as the result of polarization of the value system of economic agents which, in its turn, leads to autonomism of the contract relations on the basis of homogeneous subject structure or territorial belonging.

It is revealed in the creation of new states or administrative-territorial establishments as the result of decrease in intensity and frequency of transactions or a rupture of the contract relations with participation of residents, characterized by various territorial belonging, and also in acquisition of relative independence of the network of contract relations with the participation of subjects, characterized by a certain type of economic activity (branch associations, associations and unions). Similar autonomism of contract relations is revealed in violation of the principles of public contract, in localization of execution of public benefits (corporate universities, corporate and branch non-state pension funds, socially responsible behavior of profit oriented businesses concerning the population of the territory of their stationing and stakeholders, etc.).

At the same time the tendency of autonomism contradicts the content of paternalistic strategy of the state directed on the expansion of tools and structure of objects of state influence within the common economic space, becoming more active in the conditions of strengthening the fluctuations of macroeconomic environment. All this proves the necessity of development and realization of measures of state paternalistic policy, presupposing the implanting of ambitions focused on the effective usage of resources. Within the transition to innovatively focused model of economic development a special relevance is given to similar actions of the state in the real sector of Russian economy.

\section{References}

Armstrong J.S. Long-range forecasting, $2^{\text {nd }}$ ed. John Wiley, 1985, http://mktg-sun.wharton.upenn.edu/forecast/Longange\%20Forecasting/contents.html

Debouzy M. Permanence du paternalisme // Le Mouvement social. Paternalismes d'hier et d'aujourd'hui. 1988. № 144.

Loewenstein G., Haisley E. The Economist as Therapist: Methodological Ramifications of 'Light' Paternalism // Td. by Caplin A., Schotter A. Perspectives on the Future of Economics: Positive and Normative Foundations. The Handbook of Economic Methodologies. Vol. 1. Oxford: Oxford University Press. 2006.

Safiullin L.N., Fatkhiev A.M., Safiullina L.M. Projected trends and problems of education. Life Science Journal 2014; 11 (6s): $384-387$

Safiullin, M.R., Elstin, L.A., Shakirova, A.I. (2012). Evaluation of business and economic activity as a short-term forecasting tool. Herald of the Russian Academy of Sciences, 4, 290-294.

Gainova R.A., Shaidullin R.N., Safiullin L.N. and Maratkanova E.M. Infrastructural Component in Maintenance of Competitiveness of Region// World Applied Sciences Journal, 27(13), 2013, pp. 97-101.

Glebova I.S., Sadyrtdinov R. and Rodnyansky D. Impact Analysis of Investment Attractiveness of the Republic of Tatarstan on Fixed Investments of its Leading Companies // World Applied Sciences Journal 26 (7): 911-916, 2013.

Mitchell G. Libertarian Paternalism Is an Oxymoron // Northwestern University Law Review. 2005. Vol. 99. No. 3. P. $1245-1277$. 
Safiullin L.N., Shigabieva A.M., Mazitov V.M., Saipullaev U.A. Some methodological foundation of an innovation theory. Life Science Journal 2014; 11(6s): $388-391$.

Kundakchyan R.M., Zulfakarova L.F. Current issues of optimal capital structure based on forecasting financial performance of the company. Life Science Journal 2014; 11(6s): 368-371.

Rizzo M. J., Whitman D. G. The Knowledge Problem of the New Paternalism // Brigham Young University Law Review. 2009. No. 4. P. 905-968.

Ulesov D.V., Murtazina G., Safiullin L.N. and Saipullaev U.A. Special Aspects of Development of Business in the Knowledge-Based Economy //World Applied Sciences Journal, 27(13), 2013, pp. 189-192.

Ajupov A. Definitions of concepts scope and interaction of risk-engineering on the financial market. Life Science Journal 2014; 11(6s): 337-340.

Sugden R. Why Incoherent Preferences Do Not Justify Paternalism // Constitutional Political Economy. 2008. Vol. 19. No. 3. P. 226-248. 
